\title{
Correction: Optimisation of the Synthesis and Cell Labelling Conditions for [89Zr] Zr-oxine and [89Zr]Zr-DFO-NCS: a Direct In Vitro Comparison in Cell Types with Distinct Therapeutic Applications
}

Ida Friberger ${ }^{1}$, Emma Jussing ${ }^{2,3}$, Jinming Han ${ }^{1,4}$, Jeroen A. C. M. Goos ${ }^{1,2,3}$, Jonathan Siikanen ${ }^{2,5}$, Helen Kaipe ${ }^{6,7}$, Mélanie Lambert ${ }^{8}$, Robert A. Harris ${ }^{1,4}$, Erik Samén ${ }^{2,3}$, Mattias Carlsten ${ }^{7,8}$, Staffan Holmin ${ }^{1,9}$, and Thuy A. Tran ${ }^{1,2,3}$

1Department of Clinical Neuroscience, Karolinska Institutet, Stockholm, Sweden

${ }^{2}$ Department of Oncology and Pathology, Karolinska Institutet, Stockholm, Sweden

${ }^{3}$ Department of Radiopharmacy, Karolinska University Hospital, Stockholm, Sweden

${ }^{4}$ Centre for Molecular Medicine, Karolinska University Hospital, Stockholm, Sweden

${ }^{5}$ Department of Medical Radiation Physics and Nuclear Medicine, Karolinska University Hospital, Stockholm, Sweden

${ }^{6}$ Department of Laboratory Medicine, Karolinska Institutet, Stockholm, Sweden

${ }^{7}$ Department of Clinical Immunology and Transfusion Medicine, Karolinska University Hospital, Stockholm, Sweden

${ }^{8}$ Center for Cell Therapy and Allogeneic Stem Cell Transplantation (CAST), Karolinska University Hospital, Stockholm, Sweden

${ }^{9}$ Department of Neuroradiology, Karolinska University Hospital, Stockholm, Sweden 2022

Correction to: Molecular Imaging and Biology (2021) 23:952-962

https://doi.org/10.1007/s11307-021-01622-z

This article was updated to include the correct electronic supplementary material.

Open Access This article is licensed under a Creative Commons Attribution 4.0 International License, which permits use, sharing, adaptation, distribution and reproduction in any medium or format, as long as you give appropriate credit to the original author(s) and the source, provide a link to the Creative Commons licence, and indicate if changes were made. The images or other third party material in this article are included in the article's Creative Commons licence, unless indicated otherwise in a credit line to the material. If material is not included in the article's Creative Commons licence and your intended use is not permitted by statutory regulation or exceeds the permitted use, you will need to obtain permission directly from the copyright holder. To view a copy of this licence, visit http://creativecommons.org/licenses/by/4.0/.

Publisher's Note Springer Nature remains neutral with regard to jurisdictional claims in published maps and institutional affiliations. 